\title{
MODERN ECONOMY: FEATURES AND DEVELOPMENTS
}

\author{
Ljiljana Stošić Mihajlović PhD \\ Svetlana Trajković PhD \\ Graduate School of Applied Professional Studies, Vranje, Serbia
}

\begin{abstract}
Lately, you can often hear the most diverse signs that attempt to describe a new era in the development of the economy. They seem, however, that in this effort leading intellectuals who are not sure of the economics profession. In the constellation of diverse names that can be heard, or read more commonly in domestic and foreign professional economic literature, in this paper we deal with the issues and cases studies of some of the new economic doctrine, such as "green economy", "ecological economics", "creative economy"," knowledge economy ". Of course, this list does not exhaust all the so-called new economy.

This paper is an attempt to explain the origin and context of the emergence of certain "economy", their definition and the object of study and their importance for modern society.
\end{abstract}

Keywords: green economy, ecological economy, creative economy, the knowledge economy.

\section{INTRODUCTION}

The need for a systematic approach to the study of the most important scientific discipline of social science, economics therefore, imply new and different approaches to the economy. Growing social need for a better understanding of new processes in the economic sphere, it was found to satisfy the Fund of new scientific developments and new technical and technological achievements. Scientific thought as a way of interpreting economic social phenomenon arose from the development phase and finally led to the formation of a new and / or new dialectical approach to the economy.

The emergence of new disciplines within economics as a science, or new scientific approach to the study of economic phenomena had the logical consequence of the birth of the new, the previous century, it seems completely unfamiliar terms that have never before brought in connection with the economy.
If in explaining the new and current scientific disciplines that occur under the auspices of the economy, we start from the very first concept of economics in its original meaning of the Greek word "oikos" meaning home, house and "nomos" meaning legality, then we can just economy defined as the science that studies the laws that are related to the house, household and phenomena that are closely associated with the provision of meeting the diverse needs of man.

The new economy or the economy of a new era or a new millennium, she found it in a state of economic science, it seems, the great disintegration on the one hand, and narrow economic specialization of scientific disciplines. Note that, in principle, such a situation is not specifically related only to the social sciences and in particular the economy. The situation is similar with other so-called classical scientific disciplines. Namely, the classic scientific disciplines: physics, biology, chemistry or group of humanities, as is the case in sociology and economics, organizational sciences and law, and of course the others are set aside specifically developed rope, narrow expert specialized scientific disciplines such as nuclear physics, quantum physics, molecular biology, neurophysiology, number economies that social phenomena are viewed in the light of the natural limitations and sustainable development. Such a development of scientific disciplines has resulted in a huge fund of scientific results, especially perfected scientific methodology, and an entirely new, the development of new scientific disciplines an appropriate terminology. The reason for such production or fragmentation scientific disciplines can be found in the fact that the 
original division between classical scientific disciplines, particularly in the natural and social sciences was so sharp, so that the utilization of scientific postulates was incomplete. In fact, between the classical disciplines roughly classified into groups of natural, social and technical sciences created the so-called unused, no man's land. This space, in fact, was the breeding ground for, so to speak fragmentation science, and stronger links in some cases even delete sharp boundary between particular between individual sciences.

This process can be observed in time to locate the middle of the twentieth century, when there are new scientific disciplines, such as, for example, physical chemistry, biochemistry, biophysics, geochemistry, statistical mathematics, statistical physics, environmental economics, green economics, economics environmental, economic survival and dr. In such a development trend of Sciences appears intact, until then unknown constellation of new scientific disciplines related to economics as a science framework. They were built connections and relations, coins and titles which are sooner or later become generally accepted, or were adjusted in line with the trends of development of science and the interests of society for new and innovative effects.

\section{REASONS OF NEW SCIENTIFIC DISCIPLINE IN THE ECONOMY}

It is now absolutely certain is that as the main cause for the emergence of new scientific disciplines were in fact change and the need to take human society, and consequently science, constantly adapting to the changes that man can not, or only to a limited extent to affected. After all, scientist and creator of cybernetics Norbert Wiener ${ }^{1}$, has long been rightly observed that the most fertile areas for development in science lie in the part that remained neglected

\footnotetext{
${ }^{1}$ See more: Winer, N., "The Human Use the Human Beings", New York, 1954 and Winer, N., "Cybernetics and Society", Nolit, Belgrade, 1973. 18
}

unjustifiably discriminated between a single scientist who would thoroughly know all the preoccupations in the intellectual domain of your time. Science is actually reduced to the job highly specialized group of people, so-called specialists for each specific scientific discipline. It is evident that today, few can find scientists in general terms can be called physicists, mathematicians, or economists or even psychologists. Mainly happiness specialists for specific parts in specific disciplines.

The situation as such, certain that she could not stay long, and the reason for this is certainly the rapid changes and needs of the people that, because of mere survival, quickly, as soon as possible, adapt to the increased changes. The modernization of the economy, realized the development of new, previously completely foreign and unknown economic science disciplines is conditioned by a number of scientific disciplines to look at and can not connect with the economy. In the following we will try to further explain this attitude. The impetus to the development of new economic discipline and have given:

- Physics and its revolutionary development - modern physics leaves static Newton's understanding of the universe and introduced the idea of the probability of the occurrence of natural phenomena, and thus the idea of entropy, or the idea of information.

- Biology and her, until then unheard-of development - as well as the development of physiology and neurology to the extent that the information management and behavior of living things led to valuable scientific knowledge and thus became the basis for the study and design of artificial intelligence systems, while, on the other by the development of genetics laid the foundation of the process of coding and artificial transfer of information, and finally,

- Mathematics and its development such as the development of the theory of probability and mathematical logic led to the formalization of logical functions and improving computer techniques. On the 
other hand, a significant impact on the economy of mathematics is reflected in the development of game theory, as one of the most award-winning economic theory. ${ }^{2}$

Of course, with enumerated above, we must add the contribution of intensive technological development, such as; development of new materials, new energy sources, modern infrastructure and communications, automation of the operations, and many other achievements of social and technological character.

On the other hand, as pointed out by some authors' new today actuality view, directs man towards pluralism heterogeneous references to knowledge in which science has no privileged place Karl Proper admits that "the whole doctrine rests on quicksand," and that it nothing is certain and nothing can be proved." ${ }^{3}$ Thus, in man lies primordial tendency towards change, towards finding new, innovative and original approach in adapting to new situations. Peter Drucker, the creator of scientific management believes that every organization needs to know to solve the tasks that were set yesterday as the problem, and thus free resources and energy for new, more productive challenges and tasks. Thus, economics as a science, if trying to take opportunities, must leave and discard obsolete and to get to the solution of new and anticipated challenges, which definitely represents the essence of any change, however, and changes in the economy as a science. ${ }^{4}$ The story of peacock in the penguin land, „A Peacock in the Land of Penguins" ${ }^{5}$ actually speaks about the search for balance, through various stages of adjustment and development of science as a whole, and each of them in a very different social

\footnotetext{
2 "The Sveriges Riksbank Prize in Economic

Sciences in memory of Alfred Nobel 2015 ". Nobel

Foundation. collected 12 October 2015.

${ }^{3}$ Quoted by: Ristić, D., et al, "Change

Management", Cekom books, Novi Sad, 2007, p. 19

${ }^{4}$ See moor in Drucker, P., "Management for the Future", Grmeč - Economic Review, Belgrade, 1995

${ }^{5}$ Hateley, B., Schmidt, H.V., „A Peacock in the Land of Penguins“, BerettKochler Publishers, San Francisko, 1994.
}

circumstances. This story tells of the need for a commitment to carry out the meanings of the discovery of the beauty and true prosperity if we accept diversity and realize the need for change, which can generally be transferred to the scientific field. Is worth every effort that has been done on it, so that pioneers, advocates and founders of each new doctrine in the economy belongs to a well-deserved glory and honor.

\section{GREEN ECONOMY OR ECOLOGICAL ECONOMICS}

According to the definition of UNEP (United Environment Programme) green economy it is a discipline that aims to bring about improvements fortune of people, their well-being and social justice and equality while reducing the impact on the natural environment and human environment.

The context in which it occurred, and the time of its rapid development precisely coincides with the greatest interest of man to the protection of the environment, which is every day more and more degraded man's total, but most of the economic activity. On the whole this is the last quarter of the twentieth century. In fact, it is the doctrine accepted what is already the ordinary observer highly visible and well-known: the degree of degradation of the environment is such that it represents a serious threat to people's safety, health and employment.

At that time "large fractures" in the economy, in fact definitively abandons the idea that the nature should take everything that can contribute to increasing the material well-being of man, and how the computer is the ability of restoration of natural resources. Then, as usual, in the minds of people in science and the scientific community is increasingly penetrating view that nature is not, nor can it be an inexhaustible reservoir of human resources for economic activities, on the one hand, as you can not be on the other side, too unlimited recipient or the recipient unconditional residuals human economic 
activities, such as waste gases, wastewater or solid waste material production.

Not a viable main motive is "profits at all, at any cost", because, finally came to the conclusion that earning profits at the expense of the exploitation of natural resources representative, eventually leading to a negative profit, that leads to misery and not to the welfare of the individual or nation. For the exploitation of the environment for economic activity human finally able to return like a boomerang, with all its negative manifestations, which in the final origin may have resulted reduce economic growth, declining development potential and ultimately, the collapse of the economic system as we know, calling into question the survival of the human society.

In the period before the end of the XX century, mankind and the entire science, including the science that deals with the study of man's material sphere finally recognize that it must do a turnaround in terms of return on laws preserve natural balance, which greatly disturbed just that and such human activity directed only to achieve as much as possible the mass of profits from economy activities Finally, human society is widely understood and widely accepted concept of green economy, or as some authors call the concept of ecological economics as the supreme and its legality stand out in the foreground. The most important legality of the green economy is to operate in accordance with the natural ability, and in accordance with the capacities and capabilities of natural resources and not millimeter more. Because, everything else will have a much greater negative extreme indicator than the additive coming from the increased exploitation of natural resources. Live and do business according to the requirements of sustainable development becomes the main paradigm of economic science.

At that time, the science of economics has asked the name of the appropriate terminology, so that the parallel use the terms "organic economy", "green economy," economics of sustainable development ", and everyone is just common effort to economic activities take place in accordance with my acrimony and capacities of human labor and the environment. Actually, then, as now ceased to be a clear, precise difference between these terms, ie., between human labor and the environment.

When we talk about the context in which it appeared the green economy, it is actually a period at the very threshold of the XXI century, when humanity is faced with, until then an unprecedented crisis in modern history, which showed right from the start that there will be neither short-term nor easy to overcome. Scientists engaged in research of economic phenomena have proven that the crisis is characterized matching three, interacting negative phenomena in nature and society: the depletion of natural resources, climate change and unstoppable final crisis of social and economic system that existed until then.

These crucial reasons demanded (and still seek always) urgent solutions. The solution is partly found in the shift toward environmental or green economy, which should save the men in the biological sense of the word, thus ensuring their survival, to lift them up out of their youth and poverty at the same time insisting on the protection of the nature and the environment.

The question is, whether on the basis of unequal economic development can not claim that the environment is equally compromised, so based on that we can talk about the emergence of a new scientific discipline within the framework of Economic Sciences. It is clear that there are clear regional differences in the degree of economic development but it is also clear that the problem of endangerment and endangerment of the environment a global, planetary. The paradox is that the richest regions, which contribute most to the endangerment of the environment as a whole are at least citizens. This in turn means that the economic prosperity of the rich actually paid by the poor, and vice versa. This means that the plans, programs 
and strategies of operation and directions of action for the protection and improvement of the environment are increasingly a global problem and requires full consensus of scientists and experts on the status, needs and possibilities of environmental protection.

Modern society also needs to understand and accept the fact that free, unpolluted, the original mean no longer exists or has a very limited and compromised, degraded, devastated the environment becomes a "natural" condition encountered by of contemporary human society. Devastated Environment is expanding much faster, even some of the scientists have assumed that would happen. It carries all the diseases and plagues modern man. So that disruption of the ecological balance, which is actually a process initiated human economic activity, continues and lasts, the only science that can prevent eating as the general economy and the green economy as a separate economic discipline. Her task is to harmonize economy and ecology, to bring balance to the ecological integrity of the system of man with his economic, primarily production activity. The course can not losing sight of the fact that forms the basis, a driver of economic activity that are needs and their satisfaction on the one hand, and satisfactory profit rate with the other hand. Modern society is faced with global environmental problems, starting with the evident damage the biosphere and its ecosystems, vast population of the population that today exceeds 6 billion people with a tendency to rise and even doubling by 2020 with Constant reduction or depletion of mineral and energy resources, and polluted degraded media such as water, air, soil, extinct species of flora and fauna with the constant loss of biodiversity, while displacement of people in exile. In fact, it is estimated that today more than $1 / 4$ contemporary people today is in some kind of migration or exile, many of them are refugees who sought refuge due to effects which operation occurs as a result of human economic activity and climate change.

Green economy today, despite initial success and undoubtedly contributions provided by the general development of economic thought, still looking, or rather, merely putting the framework in which the to seek answers to the accumulated problems.

In today's economy, more and more of those who advocate for the optimal combination of market, government and social control, watching all three mechanisms of decision-making on economic issues ie. production, distribution and consumption, because in every society there are all three mechanisms and in various combinations with each other. In doing so, the European countries, it seems that the optimal German "ordoliberalismus" and because evidently gives the best results. According to Wikipedia in English, "Ordoliberalism" is actually a variant of German social liberalism. ${ }^{6}$ In Germany, as economically dominant state of the European Union has been in force for an eco-social market economy (Ökosoziale Marktwirtschaft), it is the result of intellectual, ideological and social struggle and developed as a concept about which there is general agreement on the strategy for economic development.

\section{CREATIVE ECONOMY}

A new concept in the development of economic thought, which is also briskly, stands for "taking their place and position in economic science" is the concept of "creative economy". Right at the beginning we emphasize that the creators of this concept, as in the rest of the green economy concept originally not economists by

\footnotetext{
${ }^{6}$ See more at: banka.hr: Daniel Hinsht "Germany launches Europe, which runs Germany?". Also on youtube a few: Werner Bonefeld - 'From Adam Smith to Ordoliberalism: On the Political Form of Liberty Market'; Ordoliberalism (Audiopedia); Stefan Kolev on "Why does liberty need rules? The link between German and ordoliberalism F. A. Hayek"
} 
profession, but only by choice. In most cases the main proponents of this scientific discipline within the economy as a science are primarily persons who are involved in art, primarily applied, as well as technical staff.

"Creative thinking is as old as humanity itself, is timeless, ubiquitous and independently of the territory (climate), and creative individuals every civilization owes to its growth and development. The concept of the creative economy is not new, on the contrary, dating from ancient times, respectively from the moment he created a surplus of products, overcome existential problems when developed awareness of the beauty of such a category."

The latest discussions that were conducted within the scientific community over the last decade of this century have shown that there is a change in the role of the so-called traditional factors of production and the growing importance that some intangible elements such as art, symbolic or creative design attributes in the economic field. The new development paradigm favors creativity, originality, skill and knowledge. I like Hawkins points out (Hawkins, 2003: 9), creativity is not new, but the new nature and scope of the general attitude and creativity and economics, as well as the forms in which they are intertwined to create extraordinary value and wealth. Changes in consumption patterns and an increase in leisure and scope of creative elements, there is a terminology that describes the changes and the complexity of the relationship between economy and culture, technology and creativity. "Different views of the creative economy ranging from those where it is seen as a process of agglomeration of creative activities and practices, and the creation of cultural and creative clusters covering wider geographical areas (Mommas, 2009: 45-60), then as a system of professional occupations and industries

\footnotetext{
${ }^{7}$ Rikalo, M., "From prehistoric times to the creative economy: a case study of the Vinca civilization" in the Book of Contemporary evoked in the European economy: Challenges for Serbia, GKE, 2011.

aimed at the production and distribution of cultural goods, services and intellectual property rights (DeNatale, Wassel, 2007; Cunningham, 2008; Florida, 2002), and even as a holistic concept of development consideration, which deals with the interaction of culture, economy and technology in the context of a globalized world dominated by symbols, texts, sounds and images (UNDP, 2008: 4)."

The basis of the creative economy is a creative industry. Its task is exhausted in the production of a very specific and very distinct cultural and symbolic value of the product. Creative industry as the backbone of the creative economy for the results of their work has materialized product of man's imagination, ingenuity, talent and artistic expression. Its importance for the economy is measurable and evident, because it allows the creation of new jobs, very specific, which have so far not recognize the schedule in modern conditions are becoming very popular and well paid and are based on skill, talent and creativity. The creative industries were until recently, and only count toward cultural activities, such as the production and publishing of music and cinematographic works. Today in this industry includes a much broader range of activities so that they include all branches of applied art, as well as entirely new industries that the man of the twentieth century did not know or is merely suspected their existence, such as industry software products, video games, marketing and industry a whole range of, mainly service industries and products. With this in mind, it is often pointed out that creative industry in itself necessarily contains "entertainment industry", "Copyright", "Industry of free time and leisure," "The media industry", etc. Therefore, it is very heterogeneous collection of creative industries, starting from the global media, entertainment, as

\footnotetext{
${ }^{8}$ Cited in Rikalo, M., "From prehistoric times to the creative economy: a case study of the Vinca civilization" in the Book of Contemporary evoked in the European economy: Challenges for Serbia, GKE, 2011.
} 
well as those that are based on handmade products.

Thus, we can identify three elements in understanding the creative economy. The first element is definitely a man with his psycho-physical characteristics. The second element of the economic value created by actually creating a creative individual and the fruit of individual talent. The third element is inextricably linked to the previous two and represents legal protection intellectual property, which is an upgrade of the previous element, because to creativity, essentially the sole property of the individual and intangible nature.

\section{ECONOMY OF KNOWLEDGE VS. INNOVATIVE ECONOMY}

In scientific circles knowledge is emerging as the most significant growth potential. The transformation of modern societies takes place under the Silence of ICT development that lead to the development of different social relations. Contemporary economic flows are based on new ideas, for information and acquiring new knowledge and skills and less on material resources. Thus, the knowledge economy is an economy that is not based on material resources but is based on what is easier, which is not tangible and is thus more agile and competitive in the market of the product. From this point of view, knowledge-based society and economy of knowledge are perspectives of every economy and every socio-economic system. At one time, Churchill said: "The empires of the future will be empires of knowledge," this in itself indicates that economic power in the world (through economic and political power) not determined amount of material resources of a country possess, but the accuracy of that use them. But, as it can be used for good can also exhibit its negative effects, because as Einstein said, "I do not know how the Third World War will be fought, but I know it will be the fourth World War fought with sticks and stones."
In the context of the topic being addressed, should be distinguished knowledge-based economy of the knowledge economy. This is not just talking about the terminology difference, but the difference is substantial. The knowledge economy is more dependent on the management and the production of knowledge. Knowledge-based economy is more based on the specific use of knowledge, through technology, to knowledge into practice in the product. Knowledge-based economy did factor of production.

The concept of the knowledge economy is multidisciplinary and includes specialists of different profiles, as economists, as well as technicians, computer scientists, and mathematicians, chemists, physicists, and sociologists and psychologists in one word, experts from different fields.

Very often as a knowledge economy means the economy based on human capital, ie intellectual capital. One of the best definitions of knowledge indicates that this is in fact a concept that supports and motivates the creation of knowledge in the organization and motivating employees in the organization to make better use of their skills or having them encouraged to transfer knowledge in accordance with the objectives of the organization.

The concept of this scientific discipline within the framework of the economy may be time to tie for the second half of the twentieth century, and the works of Peter Drucker, the founder and founder science of management, which has drawn a distinction between workers workhorse and intellectual workers. While a manual worker uses his own labor physical labor to produce a finished product, a worker who is working on mental tasks generates ideas, use of knowledge and information, thus creating a head and not your hands, then knowledge is important for the process of social reproduction. The main problem lies in the fact that it is modeled and formalized knowledge but also the very process of acquiring knowledge. 
By the end of the last century, economists are more favored economies of scale. Its task was to the growing needs of modern man fulfilled completely. That could be achieved only by mass production of a wide range of goods and services rendered. In modern conditions it is evident that the new economy that is based on knowledge and the knowledge economy, will not replace the economies of scale, will only be included in their own development. The knowledge economy is based more on entrepreneurship and specific means for the realization of entrepreneurial ventures. For this reason for her to speak as an entrepreneurial economy underpinning the development of contemporary modern society. This is understandable because the entrepreneurial initiative and inventiveness represent critical factors of business success.

\section{CONCLUSION}

The main feature of the modern era is a rapidly changing and highly uncertain environment. New products and services at ever shorter intervals enter the market. At the same time sets increasingly stringent requirements of sustainable development. The key role of human capital management skills. Change is the only constant, the only thing that is certain is that everything is uncertain and that only certain changes. Today also dominates the knowledge-based economy, which is often identified with the entrepreneurial economy.

The characteristics of an entrepreneurial economy are innovation and improvement of operations in accordance with ecology and mobility of factors of production and the requirements governing sustainable development.

Thus, we can conclude that the modern economy is increasingly turning to nature and the flesh which man occupies in the natural or organic rankings. This is understandable, given that the economy is a social science that monitors developments in the economic, business or field of activity and it is normal to follow the trends in the development of science as the sum total of knowledge. So it is no wonder that now the most developed economies in Europe, the German economy is precisely its success is based on close ties with the green economy. In addition, the shift towards creative economy is just another effort to economy finds its rightful place in the set and applied scientific disciplines, hence it is not surprising that some of the main promoters of creative economy in fact experts in the sphere of applied arts. Lastly, ne of the Millennium Development Goals of the United Nations Organization, which is accepted as the main strategically goal of many countries in the world, is the knowledge-based economy or knowledge economy. The modern economy is based on a specific human trait to collect, process and use various forms of knowledge to solve problems of modern man.

\section{REFERENCES}

1. Drucker, P., „Menadžment za budućnost“, Grmeč Privredni pregled, Beograd, 1995.

2. DeNatale, D., Wassal G., (2007) The Creative Economy: A New Definition, Boston, New England Foundation for the Arts.

3. Hateley, B., Schmidt, H.V., ,A Peacock in the Land of Penguins", BerettKochler Publishers, San Francisko, 1994.

4. Mommaas, H., (2009) Spaces of Culture and Economy: Mapping the Cultural-Creative Cluster Landscape, in: King. L., O'Connor, J., (eds.) "Creative economies, creative cities: AsianEuropean perspectives", Springer.

5. Howkins J., (2003) Kreativna ekonomija - kako ljudi zarađuju na idejama, Zagreb, Binoza Press.

6. Rikalo, M., „Od praistorije do kreativne ekonomije: studija slučaja vinčanske civilizacije“ u Zborniku Savremeni izazvovi u evropskoj ekonomiji: izazovi za Srbiju, GKE, 2011.

7. Ristić, D. i saradnici: „Upravljanje promenama“, Cekom book, Novi Sad, 2007.

8. UNDP/UNCTAD - United Nations Development Programme (2008) Creative Economy Report 2008: The Challenge of Assessing the Creative Economy Towards Informed Policy-making, New York, UNDP, UNCTAD.

9. Winer, N., „The Human Use the Human Beings“, New York, 1954. i Winer, N., „Kibernetika i društvo“, Nolit, Beograd, 1973. 
10. www. Nobelprice.org. "The Sveriges Riksbank Prize in Economic Sciences in Memory of Alfred Nobel 2015". Nobel Foundation. pristupljeno 12. oktobra 2015 .

11. www. banka.hr: Daniel Hinšt: "Nemačka pokreće Europu, a što pokreće Nemačku?".
12. www.youtube com video: Werner Bonefeld - 'From Adam Smith to Ordoliberalism: On the Political Form of Market Liberty';

13. www.youtube com video Ordoliberalism (Audiopedia);

www.youtube com video Stefan Kolev on "Why does liberty need rules? The link between German ordoliberalism and F.A. Hayek." 